\title{
Identification of Sex Using Linear Skull Measures: The Importance of Imaging in Biotechnology
}

\begin{abstract}
Alile Carmo ${ }^{1 *}$; Ana Carolina Mariz² Leandro Santos $^{3}$; Marianna Torres ${ }^{4}$; Raí Santos ${ }^{5}$; Roberto Monteiro ${ }^{6}$ ${ }^{1}$ University Center CIMATEC, Department of Computational Modeling and Industrial Technology; ${ }^{2}$ Ana Carolina Ramos Mariz, Federal University of Bahia, Institute of Health, Dentistry Department, ${ }^{3}$ Leandro Brito Santos, State University of Bahia; ${ }^{4}$ Marianna Torres, Federal University of Bahia, Institute of Health, Dentistry Department; ${ }^{5}$ Rai Faustino Miranda Santos, University Center CIMATEC, Department of Computational Modeling and Industrial Technology; ${ }^{6}$ Roberto Luiz Souza Monteiro, University Center CIMATEC, Department of Computational Modeling and Industrial Technology; Salvador, Bahia, Brazil
\end{abstract}

There are several methods used in the identification process of human remains. The most of them are based on comparing of antemortem and postmortem data available. Although the technique of fingerprinting is considered more accurate in many cases, it cannot be used when the bodies are mutilated, decomposed, burned, or fragmented. This article aims to compare the metric values obtained by Galvão (1994) and Saliba (2001) to differentiate male and female through dry skulls, using the measurement of the Radiocef Studio 2 Program. It was used 16 teleradiographs (11 females and 5 males). The linear measurements used in this article were: 1. The bodies stature of the mandible; and 2. Distance Nasium-Front Nasal Spine. Several radiological techniques are used to aid the human identification process for determining sex, ethnic group, and age. The analyses of X-rays and Computer Tomography (CT) scans, antemortem and postmortem, have been an important tool for human identification in forensic dentistry, especially with the refinement of techniques acquired with the advancement of radiology and CT scans. We concluded that the knowledge of the best method by forensic dentists with a careful application of the technique and report's interpretation is essential to fulfilling the necessary characteristics for a successful identification of sex using skull measures. Keywords: Radiology. Forensic Dentistry. Sex. Cranial Measures.

The human identity is the set of own and exclusive characters of a person: physical, functional, psychic, born or acquired, such as name, age, state, profession, sex, physical defects, fingerprints. Thus, the identity could be defined as the collective aspect of a set of characteristics by which something is recognizable or known [1].

Identification is the process by which one determines the identity of a person or a thing [2]. Personal identification is essential in Forensic Medicine.

Establishing postmortem human identity is one of the significant areas of study and research in dentistry and legal medicine. These forensic sciences study the human body in various stages of postmortem: sprung, torn, charred, macerated, decomposed, and skeletonization.

Received on 20 February 2019; revised 4 March 2019.

Address for correspondence: Dr. Alile Fixina do Carmo. Avenida $60 \mathrm{Dr}^{\circ}$ Antonio Monteiro Street, Apt. \# 502, Zip Code: 41815-130, Salvador, Bahia, Brazil, phone: +55 71 988960093; e-mail: afcarmo76@gmail.com.

J Bioeng. Biotech. Appl. Health 2019;2(2):54-58.

(C) 2019 by SENAI CIMATEC. All rights reserved.
Some methods used for identification include fingerprints, anthropological and radiological examinations, genetic analysis (DNA), and dental analysis (especially in carbonization cases).

The process of human identification by radiographic comparison is a technique little used in Legal Medicine, despite presents a satisfactory and unquestionable results.

The participation of dentistry in the processes of postmortem human identification is present since the initial procedures (general identification: estimates of sex and age, ethnic group determinations, stature, diagnosis of spots or liquids in the oral cavity, definition of cause and time of death) until the irrefutable possibility of the individual identification. The skull and teeth assume relevant identification in situations of substantial destruction of the human body (spoils, fragments, bony or carbonized mortal remains) because of the higher resistance when compared to the other structures. The skull and teeth are often the only elements from which identity can be derived: race, age, stature, and sex. 
The human skeleton of children and preteenager has qualitative characteristics little pronounced, providing few or no subsidy to make possible the identification of sex. In these cases, it is required other methods to determine sex, such as DNA, sexual chromatin, or teeth. [3].

The human skeleton develops after puberty under the influence of hormones, environment, and musculature, presenting differential characteristics, such as prominences, roughness, crests, apophyses, protrusions, and structures that characterize the sexual dimorphisms.

These characteristics are more prominent and evident in men than in women, in which these characteristics are more delicate and less prominent.

Ramirez (1990) [4] defines the male skull as larger than the female, which is more rounded, childlike. The frontal bone is more upright, and the parietal is smaller; the supraorbital ridges are sharp; the superciliary arches are less protruding; the front nasal joint is more curved; the styloid apophyses are short and thin; there are occipital protuberance and unmarked necklines; the mastoid processes are smaller; the occipital condyles are broad, short, and the jawless are robust. In man, the cranial thickness is greater; the forehead tilted back; the parietal bones are larger; the glabella is prominent; the superciliary arcs are protruding; the ridges above the blunt orbital; the frontal-nasal joint is angular; the styloid apophyses are long and thick; the mastoid processes are protruding and separated (sole shoe shape); the prominent occipital protuberance and regions of muscle insertions, and the more robust jaw. The palate has a broad and shallow form in males, different from females in which it is narrower and more profound, having thinner dental arches.

The bones that form the basin and the skull have reliable characters for determining sex. However, the degree of certainty of the diagnosis varies according to the number and nature of the parts examined. For example, the ethnic group should be known to identify the sex, due to the characteristics of each group.
Nowadays, the sexual difference has been studied under metrical parameters, transforming physical and qualitative characteristics into numerical values that, submitted to statistical analysis, derive metrical relations or discriminant functions. This analysis is endowed with single or multiple variables from the same measurement bone or from various structures, depending on the population that the data were collected [5-7].

In specific populations, the use of computers and mathematical models provide more reliable and accurate results in sexual determination [8,9].

Abe (2000) [6] apud Inoue et al. (1992) agree that these models enable a less experienced examiner to discriminate sex as precisely as an experienced observer. However, the statistical analysis does not replace the experts, since their competence is essential to avoid errors.

Historically, the application of radiology in the forensic sciences was introduced in 1896, just one year after X-rays were discovered by Roentgen to demonstrate the presence of lead bullets in a victim's head. Schüller proposed the possibility of using radiological images of the facial sinuses for identification purposes in 1921.

Galvão and Vitória [11] studied skulls of the Brazilian population, belonging to individuals of known sex and age group over 20 years in 1994. They concluded that the dimensions of the foramen magnum are larger in men than in women.

Saliba [12], in 2001, carried out a study of sex determination through the area formed by the triangle of the upper face, using 168 dry skulls of adult humans, over 20 years. After analysis, the Nasium-Anterior Nasal Spine (N-Ena) measure was 57.15 to 60.06 for female and 61.25 to 63.68 for male.

The present work chooses for a more precise and rational mathematical method for sex determination and aims to compare the measures obtained by the study models of Galvão (1994) and Saliba (2001), with the criteria acquired, using the measurement performed in lateral teleradiography by the following linear measurements of the cranium: 1. Height of the mandible body and 2 . 
Nasium-Anterior Nasal Spine by the program Radiocef Studio 02. Therefore, we proposed:

1. To verify the existence of sexual dimorphism using two linear measurements, performed by the program Radiocef Studio 2, in lateral teleradiography, belonging to individuals of known sex;

2. To check the degree of correctness of the values found in dry skulls, in the studies surveyed, with the radiographic values obtained.

The sample consisted of lateral cephalometric radiographs of 16 individuals (11 female and 5 male), without previous orthodontic treatment and without presenting moderate to advanced bone loss. The IOBA Clinic provided the samples' data. All the individuals showed balanced facial profiles and absence of retrognathia or prognathia of the bone bases and typical vertical pattern. All radiographs were performed on the same Orthophos Panoramic X-ray apparatus from Siemens, with the same distance and intensity. The procedure was carried out by a single examiner to avoid discrepancies between the measures obtained. The values analysed were obtained by marking the points Nasium (N), Mental (Me), Infradental (Id) and Anterior Nasal Spine (Ena) by the program Radiocef Studio 02 and the measurement of the following linear measures: height of the mandible body (Id-Me) and distance Nasium-Anterior Nasal Spine (N-Ena) (Figure 1).

These values were compared with those found in the researched literature. For the height of the mandible body, the values used as parameters were those found by Galvão in 1994 [11] (Table1). The study of Saliba (2001) [12] was used for the previous Nasium -Anterior Nasal Spine measure, considering this study presented statistically significant differences for the confirmation of sexual dimorphism, in agreement with earlier studies - Peixoto (1931) [13] and Ávila (1958) [14] (Table 2).

We compared the authors, and it showed that the mandible body height (Id - Me) for the measurement in millimeters, when compared both sex, had a compatibility of $27.27 \%$, with the values found by Galvão [11] in 1994 for females; and $100 \%$ for males (Table 3 ). There was an agreement with $81.81 \%$ to female and $80 \%$ for the male when compared the distance Nasium-Anterior Nasal Spine (N-Ena) in millimeter, with the study of Saliba (2001) [12] (Table 3). According to the proposed comparison and applied methodology, we conclude that:

1. Linear Nose-Spine (N-Ena) measurements, considered as acquired in human skull belonging to known sex, showed compatibility with Saliba (2001) [12] for sexual differentiation;

2. For the measurement Height of the mandible body (Id-Me), in the same study, a concordance of $27.27 \%$ was found with the values found by Galvão (1994) [11] for the female sex, and $100 \%$ of compatibility for males;

3. Among the two measures analysed, the NasiumAnterior Nasal Spine (N-Ena) measurement demonstrated more excellent reliability in the obtained results.

Due to the variety of methods available, the legal dentistry professional can choose the method that best fills the characteristics necessary for the success in the sex identification, taking care in the correct application of the technique and the accurate interpretation of the results.

\section{Acknowledgements}

We would like to thank CIMATEC, Federal University of Bahia (UFBA) (School of Odontology, Department of Radiology) and clinic IOBA for all support in the development of this study.

\section{References}

1. Ferreira, A.B.H. Mini Aurélio século XXI - O minidicionário da língua portuguesa. Rio de Janeiro: Nova Fronteira, 2004;(5).

2. França, G.V. Medicina Legal. Rio de Janeiro: Guanabara Koogan, 2004;(7).

3. Duz, S.A. Determinação do sexo através da cromatina sexual na polpa dentária e sua importância pericial [dissertação]. Piracicaba: UNICAMP/FOP, 2000. 
Figure 1. Cephalometric points and linear measurements of the skull.

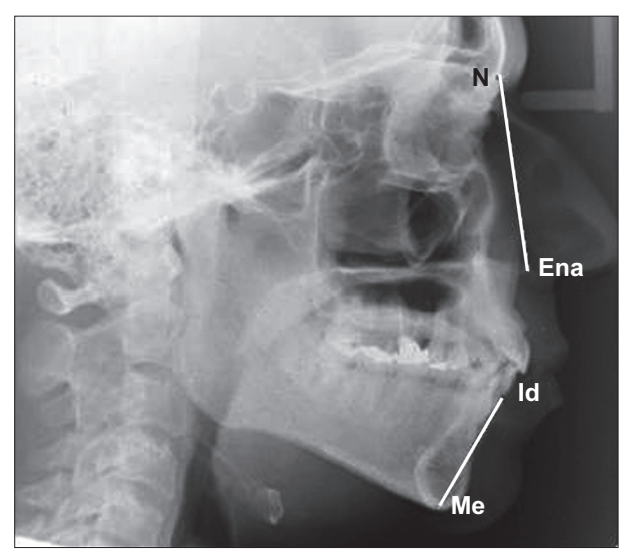

Table 1. Parameter height of the mandible body (Id-Me) were found by Galvão (1994) [11].

\begin{tabular}{lrrrrr}
\hline & \multicolumn{2}{c}{ Male } & \multicolumn{2}{c}{ Female } \\
\cline { 2 - 3 } Parameter & Confidence & Probable & Undetermined & Confidence & Probable \\
$\begin{array}{l}\text { Height of the mandible body } \\
(\text { Id-Me) }(\mathrm{mm})\end{array}$ & $>41.00$ & $33.50-41.00$ & $31.00-55.50$ & $<27.00$ & $27.00-31.00$ \\
\hline
\end{tabular}

Table 2. Nasium-anterior nasal spine measure by Saliba (2001) [12].

\begin{tabular}{lccc}
\hline & Minimum & Normal & Maximum \\
\hline Female & $57.15 \mathrm{~mm}$ & $58.61 \mathrm{~mm}$ & $60.06 \mathrm{~mm}$ \\
Male & $61.25 \mathrm{~mm}$ & $62.56 \mathrm{~mm}$ & $63.68 \mathrm{~mm}$ \\
\hline
\end{tabular}

Table 3. Data result.

\begin{tabular}{ccccc}
\hline Sample & $\begin{array}{c}\text { Sex } \\
\text { (Id-Me) }\end{array}$ & $\begin{array}{c}\text { Body height of the jaw } \\
\text { (N-Ena) }\end{array}$ & $\begin{array}{c}\text { Distance nasium-anterior } \\
\text { nasal spine }\end{array}$ & City \\
\hline 1 & $\mathrm{~F}$ & $32.81 \mathrm{~mm}$ & $53.22 \mathrm{~mm}$ & Salvador \\
2 & $\mathrm{~F}$ & $29.12 \mathrm{~mm}$ & $50.55 \mathrm{~mm}$ & Salvador \\
3 & $\mathrm{~F}$ & $28.69 \mathrm{~mm}$ & $57.40 \mathrm{~mm}$ & Salvador \\
4 & $\mathrm{~F}$ & $38.70 \mathrm{~mm}$ & $57.19 \mathrm{~mm}$ & Salvador \\
5 & $\mathrm{~F}$ & $30.89 \mathrm{~mm}$ & $44.97 \mathrm{~mm}$ & Salvador \\
6 & $\mathrm{~F}$ & $39.94 \mathrm{~mm}$ & $57.93 \mathrm{~mm}$ & Salvador \\
7 & $\mathrm{~F}$ & $39.36 \mathrm{~mm}$ & $60.41 \mathrm{~mm}$ & Salvador \\
8 & $\mathrm{~F}$ & $35.01 \mathrm{~mm}$ & $57.45 \mathrm{~mm}$ & Salvador \\
9 & $\mathrm{~F}$ & $39.44 \mathrm{~mm}$ & $59.95 \mathrm{~mm}$ & Salvador \\
10 & $\mathrm{~F}$ & $36.04 \mathrm{~mm}$ & $59.40 \mathrm{~mm}$ & Salvador \\
11 & $\mathrm{~F}$ & $32.62 \mathrm{~mm}$ & $59,92 \mathrm{~mm}$ & Salvador \\
12 & $\mathrm{M}$ & $40.82 \mathrm{~mm}$ & $61.61 \mathrm{~mm}$ & Salvador \\
13 & $\mathrm{M}$ & $36.55 \mathrm{~mm}$ & $63.37 \mathrm{~mm}$ & Salvador \\
14 & $\mathrm{M}$ & $37.99 \mathrm{~mm}$ & $56.18 \mathrm{~mm}$ & Salvador \\
15 & $\mathrm{M}$ & $34.04 \mathrm{~mm}$ & $61.31 \mathrm{~mm}$ & Salvador \\
16 & $\mathrm{M}$ & $41.00 \mathrm{~mm}$ & $63.39 \mathrm{~mm}$ & Salvador \\
\hline
\end{tabular}


4. Francesquini, M.A. Dimorfismo sexual por medidas da face e base do crânio e sua importância pericial. Dissertação de Mestrado-Faculdade de Odontologia de Piracicaba-UNICAMP, 2001, São Paulo.

5. Ramirez, A.I.C. Identificacion Forense. México: Trillas, 1990;(1):19-22.

6. Abe, D.M. Avaliação do sexo por análise de função discriminante a partir de dimensões lineares do cranio. Tese de Mestrado-Faculdade de Odontologia de Piracicaba-UNICAMP, 2000, São Paulo.

7. Carvalho, S.P. M. A utilização de imagens na identificação humana em Odontologia Legal. Radiologia Brasileira, 2009; 42(2):125-30.
8. Galvão, L.C.C., Vitória, E.M. Investigação do sexo através do forame magno. [Apostila]. Salvador: Universidade Federal da Bahia, 1994.

9. Saliba, T.A. Determinação do sexo através da área formada pelo triângulo da face superior. Tese de DoutoradoFaculdade de Odontologia de Piracicaba-UNICAMP, 2001, São Paulo.

10. Galvão, L.C.C. Identificação do sexo através de medidas cranianas. Tese de Mestrado-Faculdade de Odontologia de Piracicaba-UNICAMP, 1994, São Paulo.

11. Peixoto, A. Medicina Legal, São Paulo: F. Alves,1931;(6):363.

12. Ávila, J.B. Antropologia Física. Rio de Janeiro: Agir. $1958 ; 138$. 